\title{
Learning to cope with water variability through participatory monitoring: the case study of the mountainous region, Nepal
}

\author{
Santosh Regmi, Jagat K. Bhusal, Praju Gurung \\ Society of Hydrologists and Meteorologists (SOHAM Nepal), New Baneshwor, Kathmandu, Nepal, e-mail. \\ sregmi11@yahoo.com
}

\section{Zed Zulkafli}

Universiti Putra Malaysia, Serdang, Faculty of Engineering, Department of Civil Engineering, 43400 UPM Serdang, Selangor Darul Ehsan, Malaysia

\section{Timothy Karpouzoglou}

Public Administration and Policy Group, Wageningen University \& Research, Hollandseweg 1, 6706 KN Wageningen, Building 201, de Leeuwenborch, Netherlands

\section{Boris Ochoa Tocachi, Wouter Buytaert}

Department of Civil and Environmental Engineering, Imperial College London, South Kensington Campus, London SW7 2AZ, United Kingdom

\section{Feng Mao}

University of Birmingham, School of Geography, Earth and Environmental Sciences, Edgbaston, Birmingham B15 2TT, United Kingdom

\begin{abstract}
Participatory monitoring allows communities to understand the use and management of local water resources and at the same time develop a sense of ownership of environmental information. The data generated through participatory monitoring of stream flow and rainfall generate evidences to corroborate local people's experiences with changing water resources patterns. In this study we evaluate the potential of participatory monitoring of hydrological variables to improve scarce water supply utilization in agriculture. The case study site is the Mustang district in Nepal, which is located in the Upper Kaligandaki River Basin in the Himalayas with unique and complex geographical and climatic features. This region is characterized by a semi-arid climate with total annual precipitation of less than $300 \mathrm{~mm}$. Water supply, agricultural land, and livestock grazing are the key ecosystem services that underpin livelihood security of the local population, particularly socio-economically vulnerable groups. An analysis of the measured stream flow data indicate that annual flow of water in the stream can meet the current crop irrigation water needs for the agricultural land of the research site. The data provide local farmers a new way of understanding local water needs. Participatory monitoring would contribute to an optimization of the use of ecosystem services to support economic development and livelihood improvement.
\end{abstract}

Keywords: ecosystem services, water, participatory monitoring, irrigation, agriculture, Nepal

Submitted 29 August 2018, revised 16 December 2018, accepted 28 March 2019

\section{Introduction}

\subsection{Climate change and mountain water resources}

Mountains are unique regions for their scenery, their climates, their ecosystems and the large portfolio of ecosystem services they supply. Mountains provide key resources for human activities well beyond their natural boundaries; and they harbor extremely diverse cultures in both the developing and the industrialized world (Beniston 2005). Mountain regions provide more than $50 \%$ of the global river runoff, referred to as "water towers", sources of fresh water for the adjacent low land while more than one-sixth of the Earth's population relies on glaciers and seasonal snow for their water supply (Viviroli et al. 2007). The impacts of climatic change on hydrology are likely to have significant repercussions not only in the mountains themselves but also in populated lowland regions that depend on mountain water resources 
for domestic, agricultural, energy and industrial purposes (Beniston 2003; Eriksson et al. 2009). It is widely believed that an increase in the agricultural water use efficiency is the key to mitigating water shortage and reducing environmental problems (Deng et al. 2015) and data scarcity is still a major bottleneck for improving water resources management (Buytaert et al. 2012). There is growing evidence of increasing frequency of climatic extremes (both precipitation and temperature) especially in mountainous regions (Gautam et al. 2013). Viviroli et al. (2011) concluded that more detailed regional studies and more reliable scenario projections are urgently required for effective management of mountain water resources.

Water based ecosystem services are particularly important to the economies of low-income developing countries (WRI 2003). In the Nepal Himalayas rangelands are considered critical ecosystems that provide multiple services which support local livelihoods (Aryal et al. 2013). Water plays a key role to improve the livelihood through increasing agricultural production by improving the irrigation mechanism of agricultural land. The primary exposure to climatic variability is decrease in snowfall, showing most adverse impacts on livelihoods of study area (Kagbeni Village Development Committee). Except for glacial melt water, snow is the most crucial input factor for cultivation as well as food for animals (Duns 2011).

Here, agriculture is an important production sector inextricably linked to the availability of water and watershed-based natural resources. In the country $65.6 \%$ of people are engaged in agriculture (Ministry of Agricultural Development 2013) for their livelihood and economic supplement. About $50 \%$ of the cultivable area is irrigated. Although the country is rich in water resources, its utilization and management are very limited. A preliminary assessment reveals that forest and water resources have significant livelihood impact at the household level in Nepal, especially for the poor. The increased availability of irrigation water has helped in agricultural production and productivity, cropping intensity, and increased employment opportunities for the poor households (Pant et al. 2005). Local communities in the mountain areas are already experiencing major changes in climate, which have manifested in terms of reduced water availability, rising temperatures, and a shift in growing seasons - all of which impact agricultural production (Kotru et al. 2014).

Warming trends have been observed in most of the Himalayan region and the Middle Mountains (Shrestha et al. 1999). The precipitation extremes show increasing trends in total and heavy precipitation events in Nepal and there is strong evidence that precipitation intensity will also increase in the future (Baidya et al.
2008). Nepal receives $79.6 \%$ of annual precipitation during monsoon season whereas $4.2,3.5$ and $12.7 \%$, during post monsoon, winter and pre monsoon seasons respectively (PANO 2009). The temporal and spatial variability in precipitation induced by causes of climate changes resulted into snow accumulation in the ground and field; and snow melt acceleration due to rises in temperature has underpinned the diminishing of water sources and has resulted into conflicts among the households in the mountain area (Bhusal, Subedi 2014).

Apple farming in Nepal started in the Kali Gandaki Valley before the 1960 but first commercial Apple farming in Nepal started at Marpha, Mustang where horticultural farm was established and introduced new varieties of apples and production methods in 1966. A high market value followed by climatic suitability, labor scarcity, and land availability was found to be responsible for the expansion of apples (Manandhar et al. 2013). Because of this reasons many farmers practice a combination of apple farming and cereal crops. The introduction of new crops having different water and irrigation needs, combined with changing precipitation patterns may challenge the traditional methods of irrigation and water management practiced within the community.

\subsection{Participatory monitoring for water resources management}

"Participatory research" is an approach which argues that research has greater relevance when representatives of the targeted beneficiary group (or groups) actively participate in the research process (Sutherland 1998). Monitoring of resource use by professional scientists is often costly and hard to sustain, especially in developing countries, where financial resources are limited (Danielsen et al. 2005). Successful implementation of communitybased monitoring programs requires ongoing partnerships between local communities, individuals, and development and state monitoring institutions including academic or government scientists (Johnson et al. 2014). Local community-based monitoring is particularly relevant in developing countries, as it can provide high quality data to help fill observational voids, support rapid decisions to solve the key threats affecting natural resources, and empower local communities to better manage their resources and refine sustainable strategies to improve local livelihoods (Danielsen et al. 2009; Walker et al. 2016). The concept of participatory approach becomes an increasingly popular approach to undertake science and conduct monitoring, because it provides an excellent way to engage with the public whose participation allows for cost- 
-efficient collection of data (Buytaert et al. 2014; Pocock et al. 2014).

Volunteer monitoring programs may have positive effects on developing local capacity in relatively short time frames, significantly increase the political participation, personal networks, and feelings of community connectedness among volunteers (Overdevest et al. 2004). A high degree of community engagement is likely to result in observable changes in policy towards sustainable development and environmental management because policy-makers and local stakeholders were included in the same process (Fraser et al. 2005).

For instance in a rural Andean watershed, the participatory monitoring approach involving youth in research stimulated improved management of both land and water resources, and could be applied in other small rural watersheds in developed or developing countries (García, Brown 2009). Other research on integrated participatory approach of monitoring at the Upper Ruvu Sub-Basin, Tanzania perceived that, local people's help in identifying appropriate sites for installation of instruments, protecting the instruments against any type of vandalism and minimizing the costs for installation and monitoring (Gomani et al. 2010).

Intricate social institutions have emerged in various mountain regions to manage the common water resources for irrigation (Bandyopadhyay, Gyawali 1994). Water resource management is a multi-actor, multi-scale, and dynamic decision making process in a complex socioecological system (Elsawah et al. 2015). The community involvement in the citizen science projects is of benefit to policy makers (Hollow et al. 2015).

A major challenge of resource in participatory monitoring systems is their maintenance over the long term, especially if they empowered local community to promote greater local autonomy in resource management but are vulnerable to funding uncertainty and challenged institutional power relationships (Constantino et al. 2012). To overcome the limitations, stakeholder participation in water resources monitoring must be institutionalized, creating organizational cultures that can facilitate processes where goals are negotiated and outcomes are necessarily uncertain. In this light, participatory processes may seem very risky, but there is growing evidence that if well designed, these perceived risks may be well worth taking (Reed 2008).

\section{Research question}

The major research question of this study is: how does a participatory monitoring approach of rainfall and stream-flow data collection help develop a better understanding and quantification of water resources availability and improve their management at the local scales? In this paper, we aim to provide a hydrological analysis of the availability of water as a key ecosystem service and local distribution mechanisms. An assessment of water availability is the first important step in places where low flows are predominant within the entire range of discharge. To do this we follow a participatory approach, whereby non-scientists are actively involved in the process of generating new knowledge regarding their water resources.

\section{Methodology}

\subsection{Selection of study area}

Based on available literature a case study site at the scale of a Village Development Committee (VDC)'s administrative area was selected; where livelihoods are fundamentally dependent on ecosystem services. A predefined set of criteria was used which included population density, pasture land, livestock, agricultural production, irrigated land and per capita income. Based on those data, the Kagbeni VDC was selected as our research site. A socioeconomic house hold survey of the five villages of Kagbeni VDC was carried out. The socioeconomic survey of five villages of Kagbeni VDC (Kagbeni, Tiri, Pakling, Phalyak and Dhakarjhong) covered 55.2\% of the total households. On the basis of all these findings the villages of Dhakarjhong and Phalyak were finally selected as the case study sites where people are mostly depended on ecosystem services and are particularly vulnerable in terms of social, economic and environmental pressure such as out migration, loss of agricultural land and water scarcity. Current management of the available water makes it insufficient for irrigation and drinking in both villages.

\subsection{Engagement of local population}

To ensure that the community people participates in the data collection procedures related to stream flow, precipitation and temperature data, the local users were involved from the initial design stage of the monitoring. The research direction undertaken was developed based on their perception of change to local water resources, such that this perception could eventually be verified scientifically through the data collected. This research would therefore be highly tailored to the interest and concerns of the local community. In most of the underdeveloped countries, rural local communities are mostly illiterate and ignorant of the reasons they are adopting primitive tools 
for livelihoods. Participatory monitoring includes understanding of methods and data uses by the local through formal and informal consultation with professionals.

A meeting was organized in the community hall of Phalyak and Dhakarjhong to discuss about the work plan. The meeting included the participation of Mukhiya the traditional leader of the local community, users group, youth club, village members, teachers and local social/ political leaders. The meeting was used as a platform to agree on a proposal for the establishment of stream flow monitoring station at the Lumbhuk stream and rainfall measurement in the village. The expected output and benefit of stream-flow and rainfall measurement were described in the meeting that is the possibility to calculate the volume of water flowing in the stream, which could guide further planning and designing on water use management and land use management. The concept of participatory monitoring was adopted for the stream flow and rainfall measurement to ensure the monitoring is sustainable for the long term by developing the sense of ownership within the community. During the meeting the community decided to provide its support to the monitoring activities. They appointed an "observer", someone in charge to read and record the daily water level data from the staff gauge installed at Lumbhuk stream and rainfall volume from the raingauge installed at Phalyak village. They took responsibility for protecting the instruments from any kind of harm such as theft, litter accumulation, or extreme climatic events. The meeting also agreed to financial support from the research project for payment to the observer for their contribution up to one year. It is to be believed that after one year local people will be encouraged to collect the data without any salary as they identify the importance of these data for improving their activities and supporting resource and risk management. Three local youths were trained in each study sties who worked as observers. The village Mukhiya had supervised the observer and all activities of monitoring of stream-flow and rainfall measurement. The objective of the research was to generate knowledge through participatory approach with capacity building of local communities. At the end of the research period, communities were enabled to gather data at the local level and, maintain and operate the equipment installed at sites. Researcher visited sites in November 2017 and found that the locals were operating equipment and using data whenever they needed.

\subsection{Data}

Data related to social and livelihood dimension were collected which are interlinked with each other. Several field visits were carried out to conduct socio-economic surveys, key informant interviews and resource mapping together with members of the community to get detailed information about the prevailing situation.

Water resource data are obtained from two sources. The first source of data is from the described participatory monitoring. The second source of data is from the Department of Hydrology and Meteorology (DHM) of Nepal. We have used stage and discharge data of Lumbhuk stream for one year and available precipitation data of Jomsom climate station.

\section{Study area}

The case study area includes Dhakarjhong and Phalyak villages of Kagbeni VDC which lies in the central Mustang region of Nepal (Fig. 1). The study villages are located at 3,210 $\mathrm{m}$ and 3,145 $\mathrm{m}$ elevation respectively. These two villages are the adjoining watered area of a single stream called Lumbhuk. The area receives strong wind and intense sunlight. It falls in the rain shadow of the Annapurna ranges that acts as barrier for orographic rainfall resulting in less than $300 \mathrm{~mm}$ annual rainfall. This is five times lower than the average annual precipitation of Nepal.

There are 33 households in Dhakarjhong village and 48 households in Phalyak village with total population of 191 and 249 respectively ${ }^{1}$. The primary occupation of the people is agricultural business. The total agricultural land area is 20 hectare and 60 hectare respectively. Another 12 hectare and 15 hectare is left barren due to the insufficient water for irrigation.

The water catchment area of Lumbhuk stream is $10 \mathrm{~km}^{2}$ at to the newly proposed stream gauging station, which is located $1.5 \mathrm{~km}$ upstream from the villages. The catchment elevation ranges from 3,257 $\mathrm{m}$ to 5,630 $\mathrm{m}$ above mean sea level (Fig. 1). The geographical structure of the catchment is rock land with little vegetation.

\section{Setup of participatory monitoring \\ 5.1. Instrumentation}

Monitoring consists of a stream gauging station and a rainfall station at the research site. The stream gauging station consists of two types of stage recording instruments: Pressure level sensors (Aquistar PT2X) with data logging system are used for automatic water level monitoring. This instrument measures and records pressure, which is transformed to stream level, temperature of water, and time of recording. It has an accuracy of $0.05 \%$. Full

\footnotetext{
${ }^{1}$ Kagbeni VDC Profile, 2011, Village Development Committee
} 

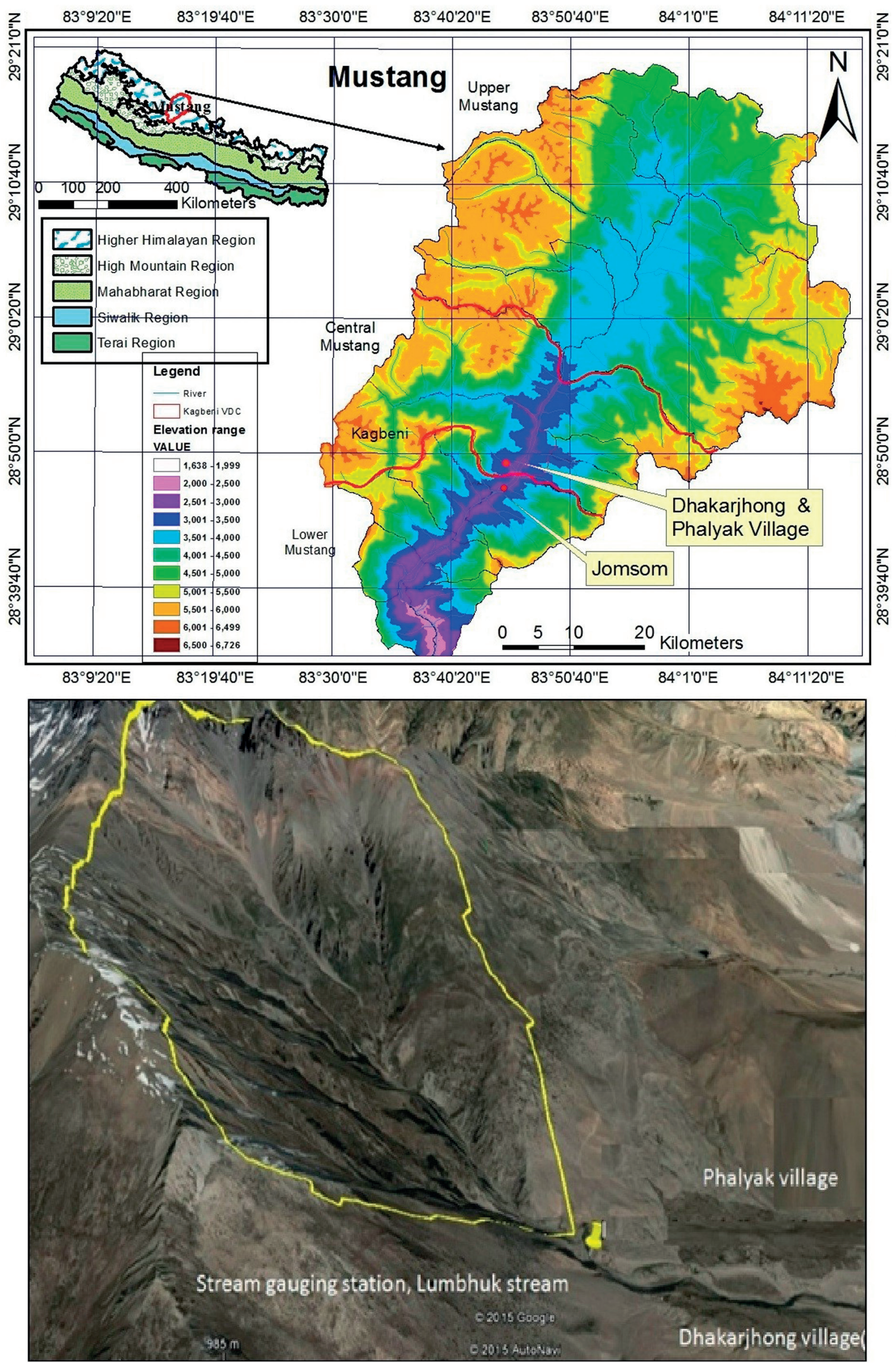

Fig. 1. The location of study area: the Dhakarjhong and Phalyak villages are located in the Kagbeni Village Development Committee jurisdiction under the Mustang District Development Committee 


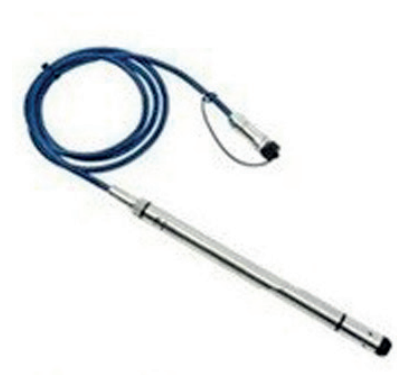

Pressure level sensor

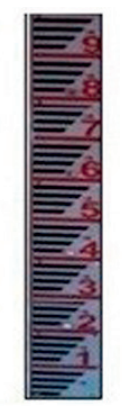

Staff gauge

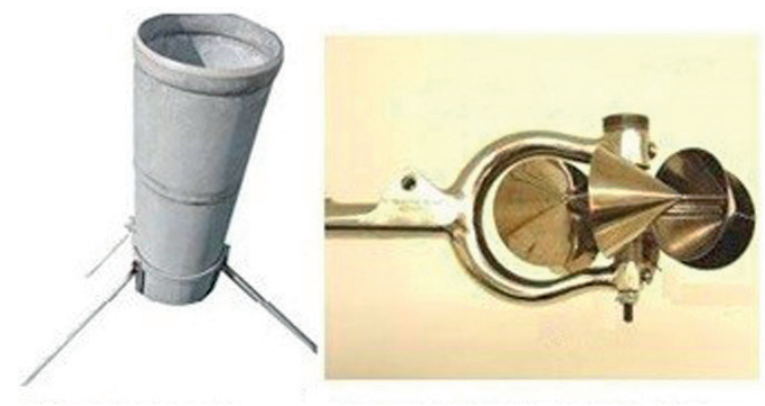

Pygmy model 6 currentmeter

Fig. 2. Type of instruments installed for stream flow and rainfall measurement

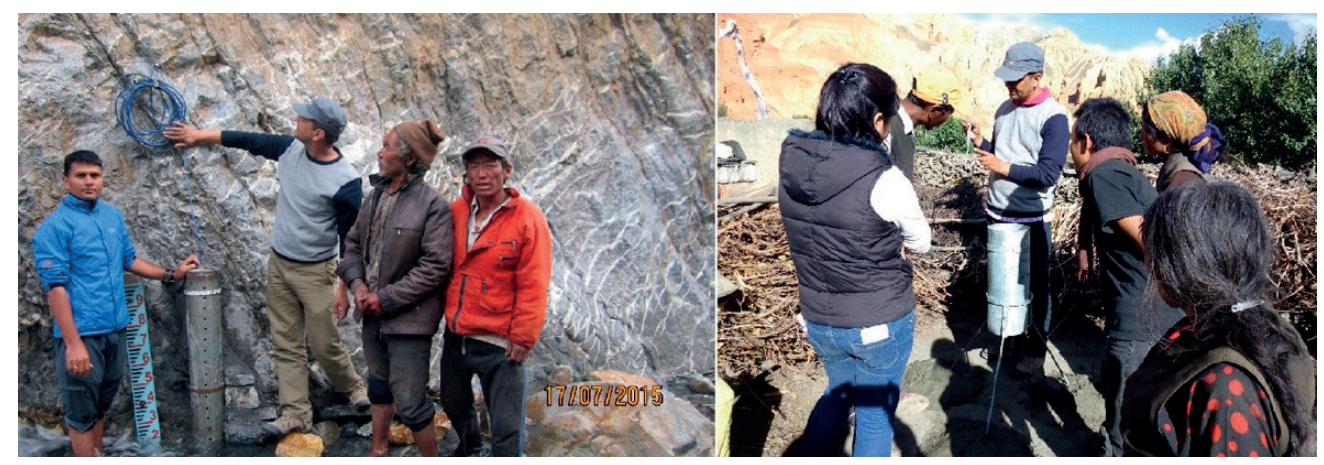

Fig. 3. Local people's participation in monitoring started at Lumbhuk stream

scale with $4 \mathrm{MB}$ of data memory. The recorded data remain safe in case of power failure. The data can be easily downloaded with the help of specialized software installed in the computer. The sensor was set to records the water level data on a 15-min interval.

The manual instrument is a staff gauge made of reinforced plastic fiber. It is graduated with $1-\mathrm{cm}$ scale with total length of 1 meter (Fig. 2, 3). Both the instruments are attached in the bank along with the stream. Manual instruments allow detect and correct errors in the automatic sensors, and to provide a proxy for the continuous measurements.

Each day at 08:00 AM an "observer" reads the stage of water level and cumulated rainfall and keeps these records. A general training on reading the stage data, measuring rainfall and maintenance of the instruments is provided to the observer after installation.

Water current velocity measurements in the stream were carried out to calculate the discharge. The Pygmy model 6 current meter was used for the velocity measurement of stream flow with its corresponding stage height to develop the rating curve of the stream.

An 8-inch diameter galvanized iron manual rain-gauge was installed at the research site, consisting of outer cylinder and inner cylinder. Rainfall that is collected by an outer funnel is channeled to an inner cylinder within and outer protective cylinder. The water collected in the inner cylinder is quantified with the help of a submerged measuring scale. The measuring scale is graduated in $\mathrm{mm}$ scale.
Additionally, hydro meteorological data from stations maintained by the Department of Hydrology and Meteorology (DHM) over that region were also collected simultaneously.

Firstly we started with the installation of monitoring instrument for stream flow measurement at Lumbhuk stream (Fig. 3). This first assessment of the stream flow is essential to understand the approximate water availability.

Local people learnt about the instruments, data collection method, use of those data and objective of installation. They guided the selection of site to install the instrument and managed the observer to carry out for the daily observation.

The youth club member also showed keen interest in these activities and take responsibility to took care of the instrument through regular inspection.

\section{Understanding communities water requirements}

People's involvement from the very beginning is important. During several field visits we sought their engagement through discussion, identifying problems and solutions. One area that local people found important was water availability for irrigation. In water scarce areas, water becomes a more limited resource than land. The crop water requirement is higher in areas which are hot, dry, windy and sunny. Lower values are found when it is cool, humid and cloudy with less wind. Surface irrigation is the common practice in the study sites. Lining canals 
and preventing leaks from the distribution system have helped greatly for increasing the water use efficiency.

We observed through questionnaire, semi-structured interviews and transect walks the strong linkages between irrigation and poverty reduction in the study area. Our detail situation analysis (Regmi, Gurung 2015) shows that irrigation is understood to benefit the poor people through higher production, higher yields, lower risk of crop failure, year-round farm and also to switch from low-value subsistence production to high-value market-oriented production. For details about the work that preceded the participatory monitoring, the reader is referred to (Bhusal et al. 2017).

Irrigation canal mapping of Dhakarjhong and Phalyak village was carried out with the villagers during the field visit of the research site (Fig. 4). The main canal which starts from intake to pond is made up of concrete whereas the distribution canals are earthen. Such canals are built on demand following traditional practices, which leads to an excessive and sub-optimal number. In both villages, a storage pond is made to collect water. Generally, from 5 PM evening to $5 \mathrm{AM}$ of next day, farmers store water in the pond and start irrigating their field during day time. These ponds, like the canals, have earthen beds promote to infiltration losses. The sizes of the ponds are small and not have high potential to store water during the surplus flow in the stream. Due to a decreasing water flow, farmers construct sub-terraces in the same field for a more efficient irrigation.

\section{Results and discussion}

\subsection{Reception and management of the monitoring by the communities}

The findings from the survey revealed that out of total sampled household, $100 \%$ people of Dhakarjung village and $88 \%$ people of Phalyak village are dependent in agriculture respectively for their livelihood whereas in the neighbouring villages Kagbeni and Tiri, locals have alternative for their income as business which is either by tourism or trading. A socio-economic survey concluded that the livelihood of the community is based on agricultural practices, which at the same time need water for irrigation. Yet based in the survey, water available for agricultural use is insufficient and furthermore stream-flow is decreasing. As a consequence, agricultural production is decreasing while cultivable land remains barren.

To gather evidence on this water uncertainty, the collective decision was made with local farmers to carry out measurements of stream-flow and rainfall to quantify the volume of water with respect to irrigation water need. The monitoring of stream-flow and rainfall is not easy to carry out without the participation of local people. Installation, monitoring and data collection by an appointed observer in a salary basis presented different difficulties. Basically, it might create unsustainable data collection due to lack of economic availability, no ownership of community, difficulty in protection of instruments and their
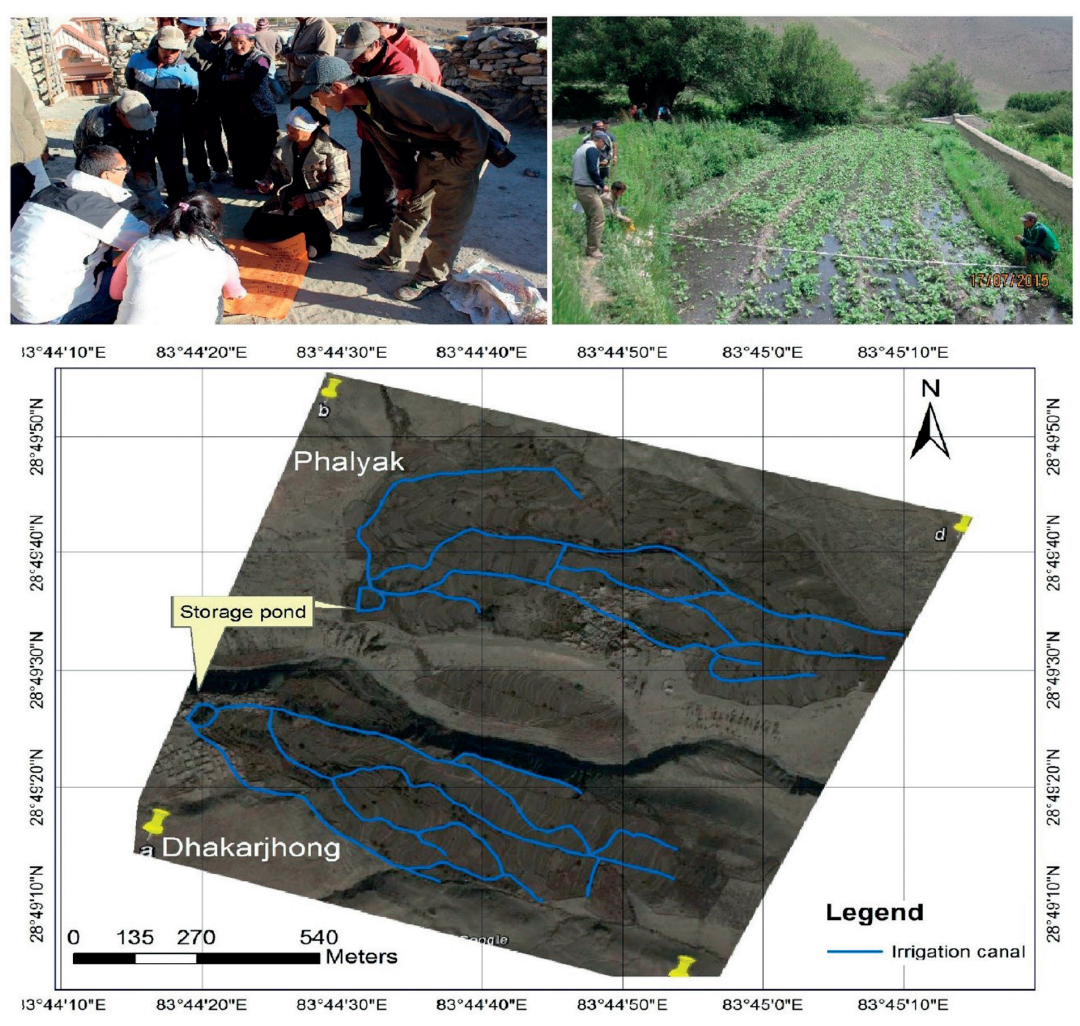

Fig. 4. Meeting with local stakeholders and member of youth club for Irrigation canal mapping (Dhakarjhong and Phalyak) and measuring the size of the field to quantify the volume of water required for irrigation per unit area of land 
maintenance, lack of knowledge generation and support in decision making process to the local people. Keeping all these difficulties in mind we engaged local people in the monitoring process which made our research objective fulfilled. Participatory monitoring is the systematic recording and periodic analysis of information that has been chosen and recorded by insiders with the help of outsiders. Communities are given knowledge to collect data (example: river water level and 24 hours precipitation) with the help of developed monograph to find the amount of water they need for each crops as per season.

Participatory monitoring helps in understanding the use of local water resources and develop a sense of ownership of the information generated by concerned communities. Increased hydrological understanding further provides the basis for communities to manage their own water resources more wisely in light of increasing pressures such as climate change. The data generated from monitoring of stream flow and rainfall for example, are evidences of the challenges that communities are experiencing on a daily basis with changing pattern of river flow and rainfall. The information generated builds up their confidence and trust in their own observations as well as makes them more proactive in their communication with government agencies. This kind of participatory monitoring has been carried out in the direct involvement of local people but there are other stakeholders (VDC, DDC, local government agencies, NGOs) who have been involved indirectly.

Involvement of several stakeholders in the monitoring processes creates the basis for effective knowledge transfer between stakeholders and for local people to bridge with the government's activities. Our study also identified that strong local leadership becomes very important for participatory monitoring to ultimately succeed in the long term. While in this study, the research team had an important role in motivating the different stakeholders such as through organizing meetings and ensuring broad attendance, in the long term this has to be done by the stakeholders themselves. State institutions need to work very closely with the communities as monitoring requirements and needs are re-evaluated in light of a changing climate and livelihood requirements.

\section{Local water allocation arrangements}

Dhakarjhong and Phalyak villages share water on a daily basis. Agreeing to this, members of Dhakarjhong village get water for two days (48 hours) whereas; members of Phalyak village get water for three days ( 72 hours). Again the turn goes to Dhakarjhong village, which is a continuous routine not on the basis of week and season.
More than 50 years ago, each household divided the water for irrigation based on the Dhongba ${ }^{2}$ or inherited area of land. In this way, each Dhongba gets 12 hours of water for irrigation. As the household property is divided into multiple Dhongba, the allocation of irrigation water get divided as well.

At present each household gets water for 3 to 18 hours depending on the size of their land (Dhongba). Each family gets their next turn of irrigation when the entire household in village is over with their turn which normally happens after 30/35 days.

One Dhongba has the right to sell their agricultural land either with allocated water hour for irrigation. This is a completely informal mechanism decided upon traditional law. Two Dhongba can share their water in return of something. For example, if one Dhongba has enough water and another has less water, the first one will provide certain hours of water to the second and in return the second has to pay back in terms of labor or water in the next season or provide Jhopa for plowing.

The study area has some aspects to be considered before implementing water use management techniques. The region is windy, sunny and arid. The soil is sandy stirring with high infiltration rate. Water collection ponds and irrigation canals are earthen, with large and sub-optimal canal networks. The size of the ponds are too small to store a sufficient amount of water during the surplus time. The region is highly vulnerable to climate change with clear symbols of changing pattern in precipitation. The intensity of precipitation is increasing with decreasing event durations. The rate of snowfall in winter season is also uneven and changing, creating the imbalance in storage of water in the catchment. Considering the above climatic and physiographic extremes and existing practices of the research site, appropriate water use management and land use management strategies should be concede.

\section{Stream flow data analysis linked with long term temperature and precipitation trend}

An analysis of temperature data from 1981-2012 of Jomsom station (DHM) shows that the annual average maximum and minimum temperature observed are $17.7^{\circ} \mathrm{C}$

\footnotetext{
${ }^{2}$ Dhongba in Dhakarjhong and Phalyak (or central Mustang) are those who get ancestral property right (eg. If there is three son in family; the middle son becomes a monk and he gets one agricultural land (plot) from his parents (which is called Dhashing); the eldest and youngest sons receive the remaining properties of their parents and divide the Dhongba in two sections. For instance, if parents own one full dhongba, it will be divided into 50/50\% after their separation and each sibling will get only half dhongba, if the parents own 2 dhongba, one dhongba will belong to each child after the separation.
} 


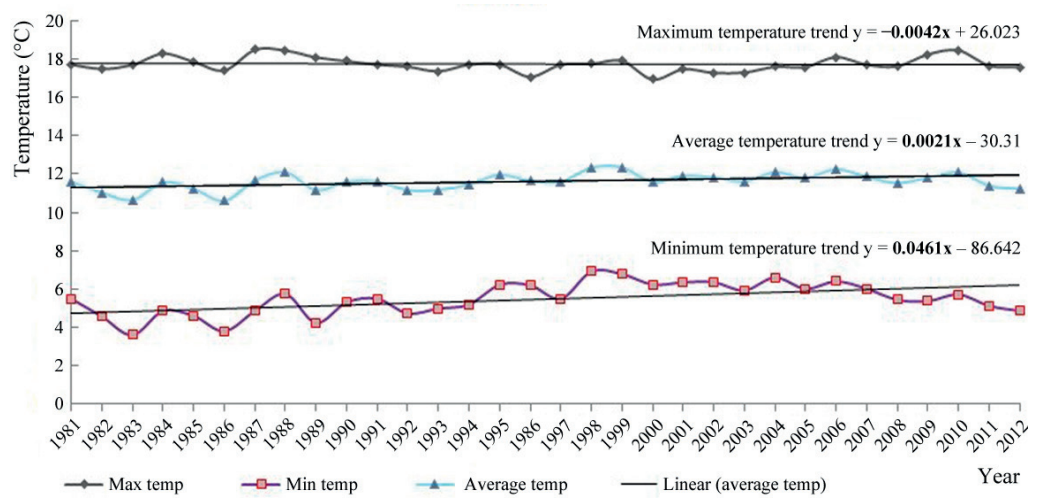

Fig. 5. Temperature trend of Jomsom station data from 1981-2012 indicates the increasing trend, particularly minimum and average temperature is increasing

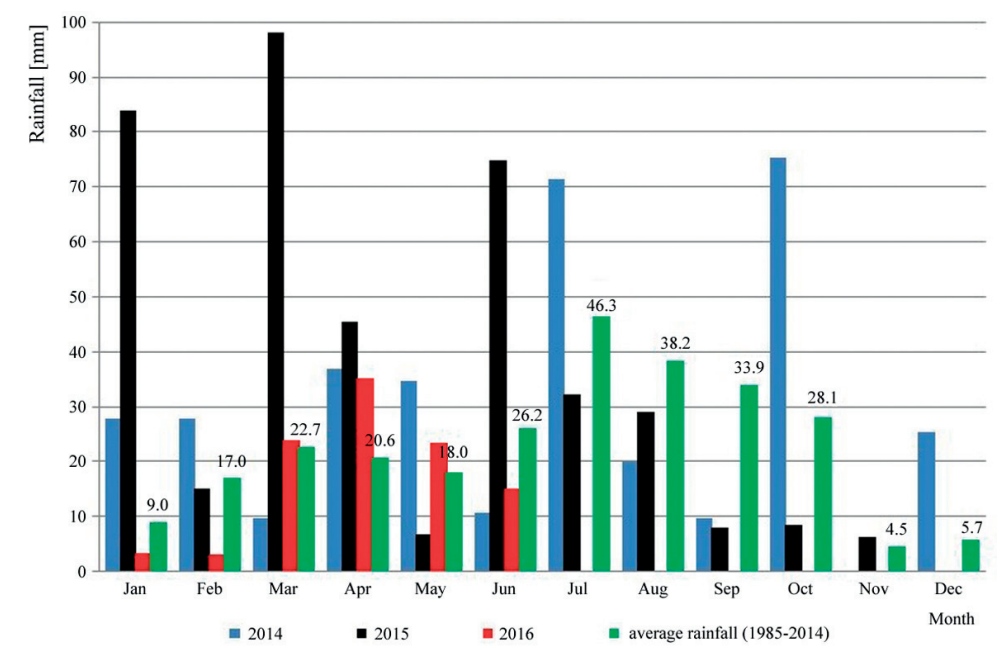

Fig. 6. Precipitation at Jomsom station of 2014, 2015 and 2016 shows the irregularity with long term average precipitation, which might be the symbol of climate change and has impact on steady stream flow

and $5.5^{\circ} \mathrm{C}$, respectively (Fig. 5). The analysis showed that the temperature is in increasing trend supporting the public opinion on climate change events including reducing snow cover area, changing pattern of precipitation, unsteady stream flow and decrease in water sources.

The analysis of rainfall data from 1985 to 2014 of Jomsom station (DHM), which is the representative station for our case study site shows the average annual total rainfall as $270 \mathrm{~mm}$. The case study area receives 53.5 percent of annual rainfall during the monsoon season (June, July, August, September) whereas 12.2, 11.8 and 22.5 percent during post monsoon (October, November), winter (December, January, February) and pre monsoon (March, April, May) seasons respectively (Fig. 6). The perennial flow of water in the stream depends on the accumulation of snow fall over the watershed during winter. The research (Chapagain, Bhusal 2013) on water balance of Upper Kaligandaki Basin shows a negative trend.

The monitoring of Lumbhuk stream flow has started from July, 2015. One year recorded stage data of that stream is presented in Figure 7. The stage of the stream is continuously decreasing throughout the year except slightly increasing in some months. The trend of stream flow with respect to rainfall shows an interesting trend. There was high precipitation (in the form of snow) on the last month of 2014 and starting months of 2015 which support the major release of water continuously up to July of 2015 (Fig. 6). After that, the precipitation decreases marking an overall decrease in water level in the stream. This provides a good evidence to support the public opinion and our assumption on the nature of stream flow. This supports that there are basically two types of precipitation; the winter precipitation in the form of snow and the summer precipitation in the form of rain that occurs in the catchment. Both play a significant role in feeding water in the stream.

Less precipitation observed in the last month of 2015 and starting month of 2016 (in the form of snow) as a result there is less storage of water in the catchment and less water flows in the stream. This could be linked to climate change but there might be other regional climatic fluctuations not captured by this study. The above scenario is also supported by the view of local youth, Mr. Govinda Bista, member of youth club in Phalyak said: »accumulation 


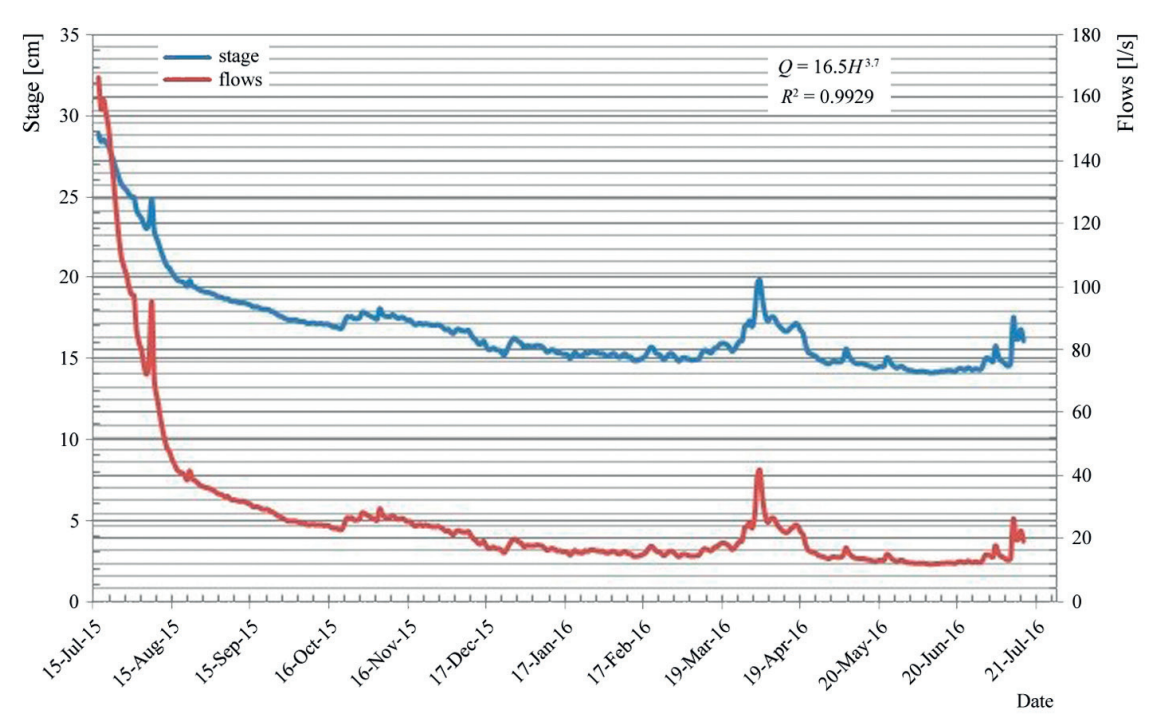

Fig. 7. Calculation of discharge based on the measured stage height with the help of rating equation developed from measured discharge with the corresponding stage height; Lumbhuk stream

of snow fall that occurs in the winter season (December, January and February) is the major source of water that discharges throughout the year«.

The stage-discharge relation (rating) of the Lumbhuk stream has developed from the measured discharge and corresponding stage height. The discharge of the Lumbhuk stream at different stage height is calculated with the help of a rating equation as shown in Figure 7.

The calculated monthly discharge in the stream of the period from July 2015 to June 2016 is shown in Table 1. The higher discharge is observed in July and lower discharge in June. The calculated monthly discharge and measured monthly rainfall of the same period are used to estimate the runoff coefficient. The total monthly rainfall volume produced by average monthly rainfall (1985-2014) in the basin is multiplied with the runoff coefficient to get an average monthly runoff in the stream. The total precipitation from July 2015 to June 2016 is $193 \mathrm{~mm}$ was used to calculate the runoff coefficient. The calculated runoff coefficient is relatively lower in some months. Therefore, the actual runoff may potentially be larger than the calculated average runoff as shown in Table 1.

Local crop calendar was prepared in participatory approach with local farmers of the research site. The crop calendar includes different activity perform in one cropping time. Type of crop, dung transfer, land preparation, seeding, weeding, irrigation and harvesting are the main activity perform in one cropping time. Local crop calendar, guidelines of Food and Agriculture Organization of the United Nations (Brouwer, Heibloem 1986) were used to identify the information related to the types of crops, growing months, and total growing days. All these information are used to calculate crop water need and irrigation water need for different crops which are commonly practices in our study site. The calculated values are shown in Table 2 .

The available irrigation water is slightly lower for naked wheat and barley but potato has higher deficit of irrigation water. For pulses, buckwheat and apple the irrigation water is sufficient. The farmers are growing a mix of crops instead of a single crop. About 33\% of agricultural land is used to cultivate apple. Cultivation of potato is carried out in the limited land and priority is given to buckwheat. This indicates that the available water in the stream is appropriate to other crops for irrigation. The available irrigation water has been calculated based on the average precipitation (Fig. 5) that occurs in the basin which may not be same in all the year.

\section{Conclusions}

The study was mainly focused in two facets, participatory monitoring of water resources and analysis of the data obtained from participatory monitoring. Participatory monitoring has established mutual advantage to both the researchers and local people. For the researcher, it is one of the easiest way for site selection, installation of instruments, protection of the instruments and data collection because presence of local people are vital in all steps. For the local people, it develops ownership, know their resources and get involve with scientists in scientific experiment to be a part of citizen science for knowledge generation that supports decision making processes.

The analysis of the stream flow data indicates that the flow of water can meet the irrigation water needs for the crops that are in practice in the available agricultural 
Table. 1 Average runoff in the Lumbhuk stream

\begin{tabular}{|l|c|c|c|c|l|c|c|c|}
\hline $\begin{array}{l}\text { Stream-flow } \\
\text { monitored } \\
\text { (month } \\
\text { and year) }\end{array}$ & $\begin{array}{c}\text { Calculated } \\
\text { monthly } \\
\text { discharge } \\
{\left[\mathrm{m}^{3}\right]}\end{array}$ & $\begin{array}{c}\text { Calculated } \\
\text { monthly } \\
\text { discharge } \\
{[\mathrm{mm}]}\end{array}$ & $\begin{array}{c}\text { Rainfall } \\
{[\mathrm{mm}]}\end{array}$ & $\begin{array}{c}\text { Runoff } \\
\text { coefficient }\end{array}$ & Month & $\begin{array}{c}\text { Average } \\
\text { rainfall } \\
(1985-2014) \\
{[\mathrm{mm}]}\end{array}$ & $\begin{array}{c}\text { Rainfall } \\
\text { volume } \\
{\left[\mathrm{m}^{3}\right]}\end{array}$ & $\begin{array}{c}\text { Average runoff } \\
\text { Runoff coefficient } \\
\times \\
\text { Rainfall volume } \\
{\left[\mathrm{m}^{3}\right]}\end{array}$ \\
\hline Jul-15 & 195,579 & 19.6 & 32.2 & 0.61 & July & 46.3 & 463,467 & 281,504 \\
\hline Aug-15 & 140,978 & 14.1 & 29.1 & 0.48 & August & 38.2 & 382,367 & 185,242 \\
\hline Sep-15 & 78,892 & 7.9 & 8.1 & 0.98 & September & 33.9 & 338,533 & 329,722 \\
\hline Oct-15 & 66,984 & 6.7 & 8.4 & 0.80 & October & 28.1 & 281,300 & 224,318 \\
\hline Nov-15 & 65,915 & 6.6 & 6.2 & 1.06 & November & 4.5 & 44,667 & 47,487 \\
\hline Dec-15 & 51,901 & 5.2 & 5.7 & 0.91 & December & 5.7 & 57,233 & 52,113 \\
\hline Jan-16 & 44,065 & 4.4 & 3.3 & 1.33 & January & 9.0 & 89,667 & 119,731 \\
\hline Feb-16 & 38,832 & 3.9 & 3.2 & 1.22 & February & 17.0 & 169,600 & 205,809 \\
\hline Mar-16 & 46,542 & 4.7 & 23.8 & 0.20 & March & 22.7 & 227,367 & 44,463 \\
\hline Apr-16 & 58,523 & 5.9 & 35.2 & 0.17 & April & 20.6 & 206,100 & 34,266 \\
\hline May-16 & 36,712 & 3.7 & 23.3 & 0.16 & May & 18.0 & 179,567 & 28,293 \\
\hline Jun-16 & 31,736 & 3.2 & 15.2 & 0.21 & June & 26.2 & 261,833 & 54,668 \\
\hline
\end{tabular}

Table. 2 Calculation of crop water need and irrigation water need

\begin{tabular}{|l|c|c|c|c|c|c|c|c|}
\hline Type of crops & Growing months & $\begin{array}{c}\text { Total } \\
\text { growing } \\
\text { period } \\
{[\text { days }]}\end{array}$ & $\begin{array}{c}\text { Crop } \\
\text { water } \\
\text { need } \\
{[\mathrm{mm}]}\end{array}$ & $\begin{array}{c}\text { Irrigation } \\
\text { water } \\
\text { need } \\
{[\mathrm{mm}]}\end{array}$ & $\begin{array}{c}\text { Available } \\
\text { volume } \\
\text { of water } \\
{\left[\mathrm{m}^{3}\right]}\end{array}$ & $\begin{array}{c}\text { Agricultural } \\
\text { land area } \\
{[\mathrm{ha}]}\end{array}$ & $\begin{array}{c}\text { Available } \\
\text { irrigation } \\
\text { water } \\
{[\mathrm{mm}]}\end{array}$ & $\begin{array}{c}\text { Time } \\
\text { of irrigation }\end{array}$ \\
\hline $\begin{array}{l}\text { Naked wheat, } \\
\text { Barley }\end{array}$ & Nov/Dec-April/May & 180 & 644 & 637 & 494,272 & 80 & 618 & 5 \\
\hline Potato & Mid April-Mid Aug & 120 & 732 & 695 & 474,218 & 80 & 593 & 4 \\
\hline Pulses, Buckwheat & June-Oct & 150 & 968 & 914 & 1075,453 & 80 & 1344 & 4 \\
\hline Apple & Sep-Aug & $\begin{array}{c}\text { several } \\
\text { years }\end{array}$ & 853 & 798 & 1607,615 & 80 & 2010 & $\begin{array}{c}\text { throughout } \\
\text { the year }\end{array}$ \\
\hline
\end{tabular}

land of the research site. Volume of stream flow mainly depends on the amount of precipitation fall in the basin. The winter precipitation (in the form of snow) has a crucial role in recharging and storing the water in the basin that is released in the summer months.

Considering the changing pattern of precipitation, geographic, climatic and social factor, appropriate water use and land use managements strategies should be concede to increase the agricultural production and so forth enhance the economic status of local farmers. This includes construction of large pond to store the water during surplus time, management of irrigation canal network, introducing of modern tools and techniques and adoption of adaptive and advance cropping practices. Drip irrigation technique was recommended during summer and daytime due to cold climate. Sprinkle irrigation is not feasible because of strong winds and scattered plot ownerships.

\section{Limitations and challenges}

Mainly data scarcity are the limitations for this study. One year stream flow data was used to calculate the runoff coefficient for this study, which is not sufficient. To validate and upgrade the runoff coefficient, continuous measurement is required. Sustainability in operating of monitoring instruments, data collection, further analysis of the data and sharing and dissemination of the results are major challenges ahead.

\section{Acknowledgement}

Data for this paper have come from the UK ESPA funded project Adaptive Governance of Mountain Ecosystem Services for Poverty Alleviation Enabled by Environmental Virtual Observatories (Mountain EVO UK NERC grant NE-K010239-1). We express our gratitude to Mountain EVO research programme.

\section{Bibliography}

Aryal A., Brunton D., Pandit R., Rai R.K., Shrestha U.B., Lama N., Raubenheimer D., 2013, Rangelands, conflicts, and society in the Upper Mustang region, Nepal, Mountain Research and Development, 33 (1), 11-18, DOI: 10.1659/ MRD-JOURNAL-D-12-00055.1 
Baidya S.K., Shrestha M.L., Sheikh M.M., 2008, Trends in daily climatic extremes of temperature and precipitation in Nepal. Journal of Hydrology and Meteorology, 5 (1), 38-51

Bandyopadhyay J., Gyawali D., 1994, Himalayan eater resources: ecological and political aspects of management, Mountain Research and Development, 14 (1), 1-24, DOI: $10.2307 / 3673735$

Beniston M., 2003, Climate change in mountain regions: a review of possible impact, Climatic Change, 59 (1-2), 5-31, DOI: 10.1023/A:1024458411589

Beniston M., 2005, Mountain climates and climatic change: an overview of processes focusing on the European Alps, Pure and Applied Geophysics, 162 (8-9), 1587-1606, DOI: 10.1007/s00024-005-2684-9

Bhusal J.K., Subedi B.P., 2014, Climate change induced water conflict in the Himalayas: a case study from Mustang, Nepal, Ecopersia, 2, 585-595

Bhusal J.K., Chapagain P.S., Regmi S., Gurung P., Zulkafli Z., Karpouzoglou T., Pandeya B., Buytaert W., Clark J., 2017, Mountains under pressure: evaluating ecosystem services and livelihoods in the Upper Himalayan region of Nepal, International Journal of Ecology and Environmental Sciences, 42, 217-226

Brouwer C., Heibloem M., 1986, Irrigation Water Management: Training Manual No. 3: Irrigation water needs, Food and Agriculture Organization of the United Nations, available at http://www.fao.org/3/S2022E/S2022E00.htm (data access 03.04.2019)

Buytaert W., Friesen J., Liebe J., Ludwig R., 2012, Assessment and management of water resources in ceveloping, semi-arid and arid regions, Water Resources Management, 26 (4), 841844, DOI: 10.1007/s11269-012-9994-3

Buytaert W., Zulkafli Z., Grainger S., Acosta L., Alemie T., Bastiaensen J., De Bièvre B., Bhusal J., Clark J., Dewulf A., Foggin M., Hannah D.M., Hergarten C., Isaeva A., Karpouzoglou T., Pandeya B., Paudel D., Sharma K., Steenhuis T., Tilahun S., Van Hecken G., Zhumanova M., 2014, Citizen science in hydrology and water resources: opportunities for knowledge generation, ecosystem service management, and sustainable development. Frontiers in Earth Science, 2 (26), 1-21, 10.3389/feart.2014.00026

Chapagain P.S., Bhusal J., 2013, Changing water regime and adaptation strategies in Upper Mustang Valley of Upper Kaligandaki Basin in Nepal, Sciences in Cold and Arid Regions, 5 (1), 133-138, DOI: 10.3724/SP.J.1226.2013.00133

Constantino P., Carlos H., Ramalho E., Rostant L., Marinelli C., Teles D., Fonseca Fonseca-Junior S., Batista Fernandes R., Valsecchi J., 2012, Empowering local people through community-based resource monitoring: a comparison of Brazil and Namibia, Ecology and Society, 17 (4), 22, DOI: 10.5751/ ES-05164-170422
Danielsen F., Burgess N., Balmford A., 2005, Monitoring matters: examining the potential of locally-based approaches, Biodiversity and Conservation, 14 (11), 2507-2542, DOI: $10.1007 / \mathrm{s} 10531-005-8375-0$

Danielsen F., Burgess N., Balmford A., Donald P., Funder M., Jones J., Alviola P., Balete D.S., Blomley T., Brashares J., Child B., Enghoff M., Fjeldså J., Holt S., Hübertz H., Jensen A.E., Jensen P.M., Massao J., Mendoza M.M., Ngaga Y., Poulsen M.K., Rueda R., Sam M., Skielboe T., Stuart-Hill G., Topp-Jørgensen E., Yonten D., 2009, Local participation in natural resource monitoring: a characterization of approaches, Conservation Biology, 23 (1), 31-42, DOI: 10.1111/j.1523-1739.2008.01063.x

Deng X.-P., Shan L., Zhang H., Turner N., 2015, Improving agricultural water use efficiency in arid and semiarid areas of China, Agricultural Water Management, 80 (1-3), 23-40, DOI: 10.1016/j.agwat.2005.07.021

Duns R., 2011, Vulnerability of livelihoods in Kagbeni Mustang district, Master Thesis, University Utrecht

Elsawah S., Guillaume J., Filatova T., Rook J., Jakeman A., 2015, A methodology for eliciting, representing, and analysing stakeholder knowledge for decision making on complex socio-ecological systems: from cognitive maps to agentbased models, Journal of Environmental Management, 151, 500-516, DOI: 10.1016/j.jenvman.2014.11.028

Eriksson M., Jianchu X., Shrestha A.B., Vaidya R.A., Nepal S., Sandström K., 2009, The changing Himalayas - impact of climate change on water resources and livelihoods in the Greater Himalayas, International Center for Integrated Mountain Development, ICIMOD, 23 pp.

Fraser E.D.G., Dougill A.J., Mabee W.E., Reed M., McAlpine P., 2005, Bottom up and top down: analysis of participatory processes for sustainability indicator identification as a pathway to community empowerment and sustainable environmental management, Journal of Environmental Management, 78 (2), 114-127, DOI: 10.1016/j.jenvman.2005.04.009

García C.R., Brown S., 2009, Assessing water use and quality through youth participatory research in a rural Andean watershed, Journal of Environmental Management, 90 (10), 3040-3047, DOI: 10.1016/j.jenvman.2009.04.014

Gautam M., Timilsina G., Acharya K., 2013, Climate change in the Himalayas: current state of knowledge, Policy Research Working Paper WPS6516, The World Bank, 47 pp., available at http://documents.worldbank.org/curated/en/4213014683501 08330/pdf/WPS6516.pdf (data access 03.04.2019)

Gomani M.C., Dietrich O., Lischeid G., Mahoo H., Mahay F., Mbilinyi B., Sarmett J., 2010, Establishment of a hydrological monitoring network in a tropical African catchment: An integrated participatory approach, Physics and Chemistry of the Earth, Part A/B/C, 35 (13-14), 648-656, DOI: 10.1016/j.pce.2010.07.025 
Hollow B., Roetman P.E.J., Walter M., Daniels C.B., 2015, Citizen science for policy development: the case of koala management in South Australia, Environmental Science and Policy, 47, 126-136, DOI: 10.1016/j.envsci.2014.10.007

Johnson N., Alessa L., Behe C., Danielsen F., Gearheard S., Gofman-Wallingford V., Kliskey A., Krümmel E.-M., Lynch A., Mustonen T., Pulsifer P., Svoboda M., 2014, The contributions of community-based monitoring and traditional knowledge to Arctic observing networks: reflections on the state of the field. Arctic, 68 (5), 28-40, DOI: 10.14430/ $\operatorname{arctic} 4447$

Kotru R., Choudhary D., Fleiner R., Khadka M., Pradhan N., Dhakal M., 2014, Adapting to climate change for sustainable agribusiness in high mountain watersheds: a case study from Nepal, ICIMOD Working Paper 2014/1, International Centre for Integrated Mountain Development, 48 pp., available at http://lib.icimod.org/record/30105 (data access 03.04.2019)

Manandhar S., Pandey V.P., Kazama F., 2013, Assessing suitability of apple cultivation under climate change in mountainous regions of western Nepal, Regional Environmental Change, 41 (2), 743-756, DOI: 10.1007/s10113-013-0531-6

Ministry of Agricultural Development, 2013, Statistical information on Nepalese agriculture 2012/2013, Ministry of Agricultural Development, Agri-Business Promotion and Statistic Division, Statistics Section, Singha Durbar, Kathmandu, available at http://moad.gov.np/public/ uploads/1009021694-YearBook\%202013.pdf (data access $03.04 .2019)$

ODOT, 2005, Appendix F - Rational method, [in:] Hydraulic Manuals, Oregon Department of Transportation - Highway Division, Engineering and Asset Management Unit, GeoEnvironmental Section, available at https://www.oregon. gov/ODOT/GeoEnvironmental/Docs_Hydraulics_Manual/ Hydraulics-07-F.pdf (data access 03.04.2019)

Overdevest C., Orr C.H., Stepenuck K., 2004, Volunteer stream monitoring and local participation in natural resource issues, Human Ecology Review, 11 (2), 177-185

PANO, 2009, Temporal and spatial variability of climate change over Nepal (1976-2005), Practical Action Nepal Office, 67 pp., available at https://practicalaction.org/file/region nepal/ClimateChange1976-2005.pdf(data access 03.04.2019)

Pant D., Thapa S., Bhattarai M., Molden D., 2005, Integrated management of water, forest and land resources in Nepal: opportunities for improved livelihood, CA Discussion Paper, no. 2, International Water Management Institute. Comprehensive Assessment Secretariat, 27 pp., available at http:// www.iwmi.cgiar.org/assessment/files_new/publications/ Discussion\%20Paper/CADiscussionPaper2.pdf (data access 03.04.2019)
Pocock M.J.O., Chapman D.S., Sheppard L.J., Roy H.E., 2014, A strategic framework to support the implementation of citizen science for environmental monitoring, final report to SEPA, Scottish Environment Protection Agency, Center for Ecology and Hydrology, Wallingford, Oxfordshire, 65 pp., available at https://www.ceh.ac.uk/sites/default/files/ hp1114final_5_complete.pdf (data access 03.04.2019)

Reed M.S., 2008, Stakeholder participation for environmental management: a literature review, Biological Conservation, 141 (10), 2417-2431, DOI: 10.1016/j.biocon.2008.07.014

Regmi S., Gurung P., 2015, A report on detail situation analysis of the research site "Dhakarjhong and Phalyak village of Kagbeni VDC", unpublished

Shrestha A.B., Wake C.P., Mayewski P.A., Dibb J.E., 1999, Maximum temperature trends in the Himalaya and its vicinity: an analysis based on temperature records from Nepal for the period 1971-94, Journal of Climate, 12, 2778-2785, DOI: 10.1175/1520-0442(1999)012<2775:MTTITH>2.0.CO;2

Sutherland A., 1998, Participatory research in natural resources, Socio-economic Methodologies. Best Practice Guidelines, Natural Resource Institute, The University of Greenwich, 19 pp., available at http://www.fao.org/docs/eims/upload/ agrotech/1911/BPG03.pdf (data access 03.04.2019)

Viviroli D., Archer D.R., Buytaert W., Fowler H.J., Greenwood G.B., Hamlet A.F., Huang Y., Koboltschnig G., Litaor M.I., López-Moreno J.I., Lorentz S., Schädler B., Schreier H., Schwaiger K., Vuille M., Woods R., 2011, Climate change and mountain water resources: overview and recommendations for research, management and policy, Hydrology and Earth System Sciences, 15 (2), 471-504, DOI: 10.5194/ hess-15-471-2011

Viviroli D., Dürr H.H., Messerli B., Meybeck M., Weingartner R., 2007, Mountains of the world, water towers for humanity: Typology, mapping, and global significance, Water Resources Research, 43 (7), DOI: 10.1029/2006WR005653

Walker D., Forsythe N., Parkin G., Gowing J., 2016, Filling the observational void: scientific value and quantitative validation of hydrometeorological data from a community-based monitoring programme, Journal of Hydrology, 538, 713-725, DOI: $10.1016 /$ j.jhydrol.2016.04.062

WRI, 2003, Ecosystems and human well-being: a framework for assessment, Millennium Ecosystem Assessment, World Resources Institute, Island Press, 245 pp. available at http:// pdf.wri.org/ecosystems_human_wellbeing.pdf (data access 03.04.2019) 